\title{
The Formation of Marxist Theory of Surplus Value
}

\author{
Yan Shi
}

Bank of Gansu Co., LTD., Lanzhou, Gansu, 730000

\begin{abstract}
Marxist theory of surplus value is founded on the basis of Marx's labor theory of value. The theory of surplus value is based on mercantilism and the theory of surplus value of David Ricardo. Adam Smith and Owen also played a certain role in the formation of Marxist surplus value theory. Marx's analysis of the subject of labor and the process of labor is the basis of historical materialism of surplus value theory. This paper analyzes the significance of the formation of Marxist surplus value.
\end{abstract}

Keywords: Marxist theory of surplus value; Classical economic theory of value; Scientific socialism

DOI: 10.36012 /fhe.v1i2.1433

\section{Preface}

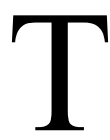

he theory of surplus value is an important theory and theoretical achievement expounded by Marx in his work Das Kapital. With the continuous development of society, the challenge of the knowledge economy to traditional economics makes Marx's theory of surplus value gain the attention of the academic circle again. According to the contents of Marx's classical texts, "labor" is a basic category commonly used in works. Starting from the historical materialism, political economy and other dimensions, the category of labor was analyzed, allowing Marx to build in his works a world outlook and methodology system with historical materialism, surplus value and the basic theories of human liberation as the core. In a modern

society with a highly developed market economy, Marx pays attention to the study of surplus value theory, which is helpful for people to analyze the influence of investment on surplus value rate from the perspective of social total capital reproduction.

\section{The theoretical basis of Marxist surplus value}

Marxist theory of surplus value helps people understand the nature of capitalist production. Before the Marxist theory of surplus value came into being, labor thought and surplus value had attracted the attention of classical economists and utopian socialists ${ }^{[1]}$.

\subsection{The theory of surplus value based on mercantil- ism}

Mercantilism came into being and capitalist mode of production developed at the initial stage. After the disintegration of feudalism in Western Europe, some economists believed that western European countries were generally short of gold and silver deposits, and commodity circulation was an effective measure to promote the increase of social wealth. The addition of product value is an important issue that people pay attention to in the field of circulation. The only way to make a profit in circulation is to take advantage of low prices as buying goods and sell them at high prices. This way of making profits has become the basic mode of business in modern society. The theory of surplus value based on mercantilism is based on the theory of alienation related to the product value. That is to say, the profit obtained by the seller of goods in the process of commodity trading is regarded as the surplus value of the goods. From the point of view of the actual content of the surplus value theory of mercantilism, the mercantilists lack the understanding of the origin and the essence of money. In the absence of an understanding of surplus value and the normal dynamics of circulation, the mercantilists did not define surplus value accurately, but the surplus value theory based on mercantilism confirms the existence of surplus value.

\subsection{Surplus value theory of British classical political economy}

William Petty, James Stuart, Adam Smith and David Ricardo are representatives of classical British political economy. Before the beginning of the first industrial revolution, William Petit, the founder of the British classical political economy, had put forward the theory that the value of goods comes from labor ${ }^{[2]}$. This view- 
point laid a foundation for the emergence of scientific labor theory of value. According to William Brady's definition of the wage of laborers, the wage of laborers is the added value of the living materials necessary to maintain the minimum life. Its wage theory can be regarded as the basic element of surplus value theory. Adam Smith saw social labor in general as a source of value. David Ricardo's theory of relative wages can be regarded as an innovation of the theory of surplus value.

2.3 The theory of surplus value of French physiocratic school

French physiocratic school is representative of French classical political economy. Quinine's theory of "pure product" and Durgo's theory of surplus value are the main contents of the French physiocratic theory of surplus value. According to the specific performance of traditional agricultural economy, Quinnae considers "pure product" as a surplus product beyond the means of production and the means of livelihood of the farmer. Like representatives of classical British politics, Quinnae also affirmed the role of wages in the lives of workers. According to the "pure product" theory put forward by Quinnae, the surplus value created by the "pure product" constructor's surplus labor. In the author's opinion, Quinnae took the capitalist operation in the agricultural field as an example to analyze the capitalist production mode. The theory of the residual value of Quinalene confirms the conclusion that the residual value comes from the production process, so it has the significance of determining the true origin of the residual value.

\subsection{Utopian socialist surplus values}

Utopian socialists, represented by Owen, put forward the concept of surplus value according to Ricardo's labor theory of value. To some extent, they understood the nature of the capitalist system and the cause of surplus value, but the utopian socialist nature they put forward restricted the theoretical depth of surplus value.

\section{The formation process of Marxist surplus value}

The theory of surplus value is not the first one put forward by Marx. Although the labor theory of value put forward by David Ricardo and Adam Smith clarified the law of development of commodity economy, they did not analyze the cause of contradictions in capitalist society and the development trend of capitalism. According to some classical economists, there is a posi- tive connection between the labor theory of value and human nature. The labor theory of value, which is derived from human nature, is not necessary for the economic relations and productivity development of their era. On the basis of absorbing the previous viewpoints and taking the practical social production as the basis, Marx analyzed the employment-labor relationship based on the capitalist model, and clarified the employment-labor basis of the theory of surplus value in the process of analyzing the labor relationship and labor process.

\subsection{Enlightenment stage of Marx's theory of surplus value}

On the basis of absorbing previous theories of surplus value, Marx first expounded the definition of surplus value in The Poverty of Philosophy. At the end of 1847, Marx put forward the concept of surplus value theory in his speech entitled Wage labor and capital. The investigation of the labor process under the system of hired labor is the main source of Marxist theory of surplus value. Based on the analysis of slave labor, corvee labor and wage labor, Marx believed that the labor contract and monetary relationship played a role in the system of wage labor to conceal workers' free labor. Under the influence of the wage labor system, the free labor carried out by laborers under the management of capitalists is also transformed into paid labor ${ }^{[3]}$.

Capitalist production process is the process of creating use value. The emergence of wage labor system makes the labor process and value increment process become the representative elements in the capitalist production process. After analyzing the production links and circulation links of the products under the capitalist mode, Marx regarded the employed workers as the main laborers in the capitalist society. The labor of workers is the source of surplus value. In capitalist labor relations, the products produced by the laborer are owned by the capitalist. After the workers use their labor to repay the capitalists for their labor revenge, they still need to satisfy the capitalists' own demands through labor, so paid labor and unpaid labor become the main forms of labor for workers in the capitalist society. The daily work tasks of workers are the result of the combination of remunerated and unremunerated labor. The plunder of the fruits of the unremunerated labor of the workers is the principal means by which capitalists accumulate wealth. From the perspective of 
the formation of Marx's theory of surplus value, Marx's analysis of the way capitalists acquire wealth and the source of surplus value has laid a foundation for the emergence of Marxist theory of surplus value.

\subsection{Formation stage of Marx's theory of surplus value}

The economic manuscripts of 1857-1858 are the product of Marx's theory of surplus value. This work mainly contains the following contents: first, the reason why the wage-labor relationship between capitalists and workers forms the market; Second, the characteristics of the employment market; Thirdly, the similarities and differences between labor and labor force; The fourth is the principle of labor commodity. When discussing the relationship between labor and labor force, Marx analyzed the duality of labor commodity. This great theoretical breakthrough can be regarded as the key factor for Marx to establish the theory of surplus value. According to Marx's view of labor ability, the exchange between capitalists and workers reflects the exchange between capital and labor ability. Capitalists possess the laborers themselves. The workers' own production of labor becomes a reflection of the capitalist's power. After summarizing the theory of surplus value in the field of classical political economy, Marx also criticized and questioned the classical political economy based on the bourgeois standpoint.

\subsection{The establishment stage of Marx's theory of surplus value}

In June 1865, Marx put forward the theory of surplus value publicly for the first time in his report Wages, Prices and Profits. The publication of Das Kapital in 1867 marked the final establishment of Marx's theory of surplus value. According to the relevant content of Marx's theory of surplus value, his understanding of capitalist market economy takes the commodity of labor force as the precondition. In other words, labor can be regarded as a special kind of commodity. Labor prices are also subject to market forces. This research method of comparing the labor force with common goods is the product of Marx's absorption and reference of the classical British political economy theory.

From the process of establishing the theory of surplus value put forward by Marx, labor dialectics can provide guidance for scientific thinking in the research of surplus value theory. The theory of labor value put forward by Marx is based on the duality of labor. (The duality of labor is closely related to abstract labor that creates commodity value and concrete labor that creates commodity use value ${ }^{[4]}$.) On the basis of analyzing the dual nature of the general formula of capital and the commodity of labor, Marx shows the essence of value increment and the source and nature of surplus value. On the basis of analyzing the contradictory internal movement of labor category, Marx clarified the internal relation between participation value and labor. Aiming at the problem that some classical economists pay too much attention to the use value of commodities in the study of labor value and surplus value, Marx analyzed the category of labor mainly from the process of product production. According to the relevant contents of Marx's theory of surplus value, the category of labor mainly involves the following contents: first, concrete labor and abstract labor; Second, private and social work; Third, dead labor and living labor; Fourth, necessary labor and surplus labor. On the level of commodities, Marx regards the two factors of commodities as the manifestation of the duality of labor, and on this basis analyzes the contradictions and conflicts of the duality of labor in the process of commodity production.

To solve the problem of surplus value, Marx used the dialectics of history and logic when he explained the process of surplus value. It also criticizes some idealist thoughts in Hegel's thought of unification of history and logic. For example, Hegel puts forward in the Lectures on the History of Philosophy that the development history of logic and the absolute idea is consis tent with the development history of thought and human history. From Marx's point of view, the unification between logic and history should not only be regarded as a problem in the field of thought but also as a problem related to practice. There is a close connection between human thinking logic movement and the process of understanding and transforming the objective world. The unity of logic and history is the unity of subjective dialectics and objective dialectics.

\section{Formation significance of Marxist surplus value}

Marxist theory of surplus value is the product of people's analysis of social and economic phenomena by using scientific historical materialism. According to the Marxist interpretation of surplus value. The sources of surplus value, the essential characteristics of capitalist production and other factors are closely re 
lated to labor, constant capital, and variable capital. After making clear the general and specific forms of surplus value, Marx also analyzed the transformation of surplus value: for example, the transformation of surplus value into industrial profit; The transformation of surplus value into commercial profit.

\subsection{Enrichment of classical economics value theory}

The scientific and systematic theoretical system constructed by Marx's theory of surplus value plays an important role in enriching the value theory of classical economics. The source of surplus value, the role of surplus value, the essence of capitalist exploitation of labor workers and the cause of capitalist social contradictions are the important contents concerned by Marxist theory of surplus value. While promoting the development of classical political economy, Marxist theory of surplus value can also enable people to analyze the economic outlook in the field of social economy with the help of scientific historical materialism.

\subsection{Provide a guarantee for the construction of sci- entific socialism}

Marxist theory of surplus value plays an important role in promoting the development of scientific socialism. Before Marx's theory of surplus value came into being, utopian socialists had affirmed the feasibility of replacing the capitalist system with ideal social system. However, after analyzing the actual content of relevant viewpoints, we can find that there is still a certain connection between the above theories and idealism.

The rational principle they put forward to criticize the capitalist system could not explain the inevitability of replacing capitalism with socialism. The emergence of Marxist theory of surplus value can deepen people's understanding of the fundamental nature of capitalism and people's understanding of the future society. Therefore, Marxist theory of surplus can provide a certain guarantee for the construction of scientific socialism.

\subsection{Provide theoretical support for the proletarian revolution}

By analyzing the role of Marx's theory of surplus value in modern world history, we can find that this theory provides certain theoretical support for the revolutionary struggle of the proletariat. Marx's theory of surplus value enables the bottom masses to understand the essential factors of the capitalist system, and the ideological consciousness it brings contributes to the development of the proletarian struggle ${ }^{[]}$. The ideological consciousness brought by Marxism to the social masses can make them understand the necessity for the people to be masters of the country, thus contributing to the struggle of the proletariat.

\section{Conclusion}

Marx's theory of surplus value is the product of the development of Marx's labor thought. Marx's analysis of the subject of labor and the process of labor is the process of constructing the historical materialism of the theory of surplus value. Labor dialectics is a scientific thinking method applied by Marx in the field of the theory of surplus value. From the perspective of Marx's theory of surplus labor value, Marx's analysis of the inherent contradictions of labor by using the theory of surplus value can help people understand the historical inevitability of the capitalist mode of production. Before Marx's theory of surplus value came into being, utopian socialists had determined the feasibility of replacing the capitalist system with the ideal social system. While promoting the development of classical political economy, the Marxist theory of surplus value can also enable people to analyze the economic outlook in the field of social economy with the help of scientific, historical materialism.

\section{References}

[1] Wang Zhenliang. On Marx's Labor Theory of Value [J]. Zhiyin Inspirational,2016(11):194.

[2] zhou hong. The logical deduction of Marx's theory of surplus value to historical materialism -- a case study of das kapital and its manuscripts [J]. Journal of xi 'an university of finance and economics,2015,28(5):108-113.

[3] meng jie. Redefinition of labor value and reconstruction of surplus value theory [J]. Political economy review,2015,6 (4):69-101.

[4] wu xuedong. The scientific nature of surplus value theory from Marx's labor thought [J]. Journal of central south university (social science edition), 2014,20(6):45-50.

[5] liu Yu. New interpretation of the labor theory of value and surplus value theory research, the Marx's two major new discovery of main content review [J]. Journal of theoretical frontiers, 2007 (17):48. 